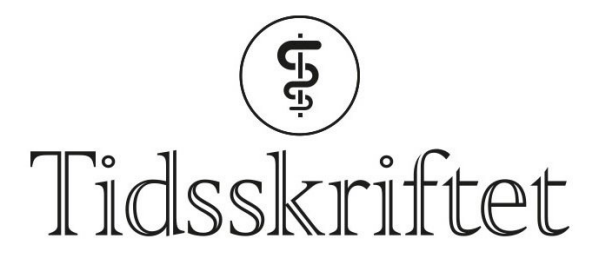

DEN NORSKE LEGEFORENING

\title{
Bakterier med syntetisk genom
}

FRA ANDRE TIDSSKRIFTER

RUTH HALSNE

Tidsskriftet

Forskere har lyktes med å bygge opp en E. coli-stamme med ferre kodoner ved å kombinere biter av DNA.

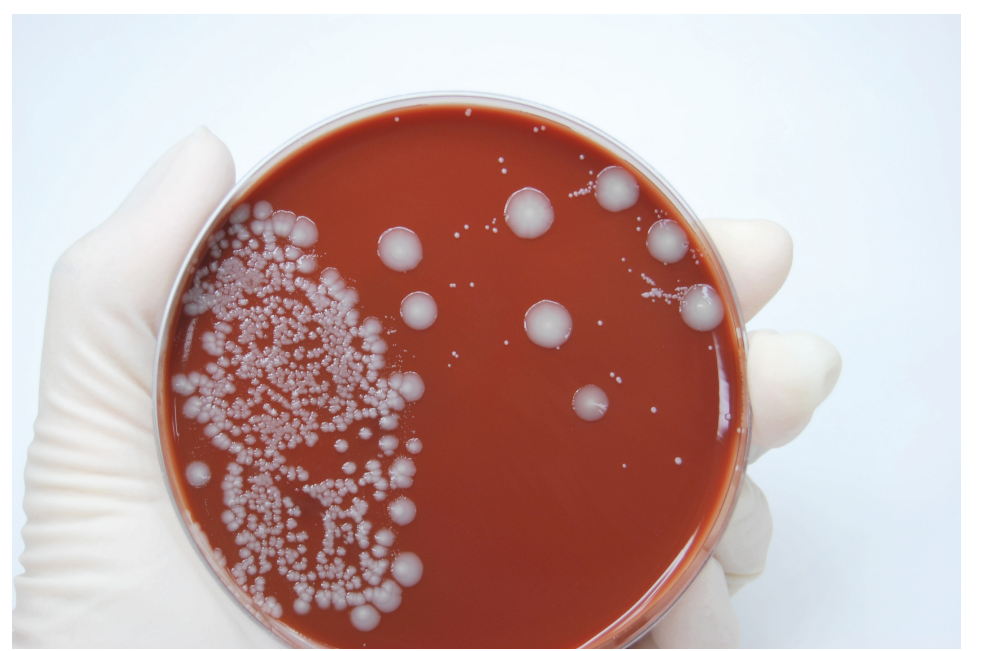

Illustrasjon: Linde1/iStock

Et kodon består av en sekvens på tre nukleotider langs en mRNA-tråd og definerer 20 essensielle aminosyrer. Totalt finnes det 64 kodoner, inkludert kodoner for start- og sluttsignal.

En forskningsgruppe i Cambridge har klart å bygge et bakteriegenom med redusert antall kodoner som holder liv i bakteriestammen Escherichia coli (1). Bakteriegenomet ble gjennomgått, og antall kodoner ble redusert fra 64 til 61 kodoner ved at to kodoner for aminonsyren serin og ett for sluttsignal ble fjernet. DNA ble kjemisk syntetisert i biter på 1 $\mathrm{kb}$ (dvs. 1 ooo nukloetider) og fordelt i åtte bakteriestammer. Ved å bruke av bakteriens naturlige system for utveksling av genetisk materiale ble DNA-bitene kombinert, og genomet komplett. Resultatet ble en E. coli-stamme med et syntetisk generert genom som kan leve og vokse under ordinære laboratoriebetingelser, dog redusert sammenlignet med vanlige E. coli-bakterier.

- Dette omfattende arbeidet med å sette sammen DNA-byggeklosser bestilt fra en leverandør er den største genomjobben som noensinne er gjort, sier Rahmi Lale, som er førsteamanuensis ved Institutt for bioteknologi og matvitenskap ved NTNU.

- DNA-sekvensering er som å lese en DNA-sekvens, men denne studien viser hvordan man 
kan skrive et helt genom. Ved å frigjøre enkelte kodoner ser man for seg at den ledige kapasiteten kan brukes til nye funksjoner. På sikt kan denne kapasiteten kanskje brukes tilå designe og syntetisere nye proteiner, sier Lale.

\section{LITTERATUR:}

1. Fredens J, Wang K, de la Torre D et al. Total synthesis of Escherichia coli with a recoded genome. Nature 2019; 569:514-8. [PubMed][CrossRef]

Publisert: 9. desember 2019. Tidsskr Nor Legeforen. DOI: 10.4045/tidsskr.19.066o

(C) Tidsskrift for Den norske legeforening 2020. Lastet ned fra tidsskriftet.no 